Swarthmore College

Works

3-1-1964

\title{
Paradox In The Aphorisms Of La Rochefoucauld And Some Representative English Followers
}

Harold E. Pagliaro

Swarthmore College, hpaglia1@swarthmore.edu

Follow this and additional works at: https://works.swarthmore.edu/fac-english-lit

Part of the English Language and Literature Commons

Let us know how access to these works benefits you

\section{Recommended Citation}

Harold E. Pagliaro. (1964). "Paradox In The Aphorisms Of La Rochefoucauld And Some Representative English Followers". PMLA. Volume 79, Issue 1. 42-50. DOI: 10.2307/460965

https://works.swarthmore.edu/fac-english-lit/37

This work is brought to you for free by Swarthmore College Libraries' Works. It has been accepted for inclusion in English Literature Faculty Works by an authorized administrator of Works. For more information, please contact myworks@swarthmore.edu. 
Paradox in the Aphorisms of La Rochefoucauld and Some Representative English Followers Author(s): Harold E. Pagliaro

Source: PMLA, Vol. 79, No. 1 (Mar., 1964), pp. 42-50

Published by: Modern Language Association

Stable URL: http://www.jstor.org/stable/460965

Accessed: 19-08-2014 19:40 UTC

Your use of the JSTOR archive indicates your acceptance of the Terms \& Conditions of Use, available at http://www.jstor.org/page/info/about/policies/terms.jsp

JSTOR is a not-for-profit service that helps scholars, researchers, and students discover, use, and build upon a wide range of content in a trusted digital archive. We use information technology and tools to increase productivity and facilitate new forms of scholarship. For more information about JSTOR, please contact support@jstor.org. 


\title{
PARADOX IN THE APHORISMS OF LA ROCHEFOUCAULD AND SOME REPRESENTATIVE ENGLISH FOLLOWERS
}

\author{
By Harold E. Pagliaro
}

Se quanto infino a qui di lei si dice fosse conchiuso tutto in una loda, poco sarebbe a fornir questa vice.

Paradiso $\mathrm{xxx} .16-18$

$\mathrm{T}$ HE BEST REMEMBERED aphorists have contrived to state new truths in brief and telling ways. Less fascinated than most authors with leaf, twig, and branch, they strike immediately for the pith. Almost every reader of their work first pays tribute to this concentration of effort with the repeated shock of joy and enlightenment that marks his response. It seems likely that such writers try to achieve a compression of statement that corresponds to the instantaneous character of their insights. Like Dante, they are stirred by the hope of economizing glimpses of eternity into single-worded statements; unlike him, they never quite despair of doing so. Anyone who has responded to the success of their efforts can appreciate the temptation to discover something about the means by which these paradoxical compositions achieve their effects, particularly those that time and again tumble their reader's complacency. It is with the ways in which those effects derive from the structural patterns of the aphorism that this essay is concerned. The method will be first to classify aphorisms according to structure and then to examine the ways in which each class affects the reader.

In order to focus on its chief concern, this study has limited itself in marked, though by no means arbitrary, ways. For example, although it would be valuable to explore the cultural climates in which the aphorists treated here weathered lifeLa Rochefoucauld, Halifax, Swift, Chesterfield, and Shenstone- the journey has not been undertaken, simply because space will not allow a responsible treatment of both the rhetorical effects of aphoristic structure and their relationship to the intellectual background against which the genre had its greatest flowering. And since for every reader who knows something about the structure of the aphorism there will be a hundred well acquainted with the French and English seventeenth and eighteenth centuries, the decision to omit that correlation seems just. The choice of aphorists needs a word of explanation too. It seemed that the omission of background material might in a degree be compensated for by a selection of authors, one or more of whom would be very well-known to most readers, or authors whose work in the genre clearly epitomizes the tradition of the paradoxical aphorism. La Rochefoucauld was of course the obvious first choice. His earliest English imitators include the prominent Halifax, Swift, and Chesterfield. ${ }^{1}$ Shenstone's presence may occasion some surprise, even among those familiar with eighteenth-century English literature. It should therefore be observed that no less a critic than Geoffrey Tillotson regards "Shenstone's few hundred aphor-

\footnotetext{
1 Generally, English aphorists who wrote after the appearance of La Rochefoucauld's maxims, 1665, produced at least unconscious imitations of his work. See J. E. Tucker, "The Earliest English Translation of La Rochefoucauld's Maximes," $M L N$, LxIv (1949), 413-415, for discussion of an anonymous edition of the Maximes published at the Hague in 1664 . By 1685 the Maximes were widely known both in the original and in English, owing to translations by John Davies and Aphra Behn. Davies' was the earlier, appearing in 1670; Aphra Behn translated only 395 of the original 504 maximes for her Miscellany, being a collection of Poems by several hands. Together with reflections on morality or Seneca unmasqued (London, 1685). By the time the second edition of Mrs. Behn's translation appeared in 1706, Swift had produced his Various Thoughts, Moral and Diverting, in the style of La Rochefoucauld. See Herbert Davis' introduction to $A$ Tale of a Tub (Oxford, 1957), p. xxxv, for the opinion that "Swift's admiration for the Maximes of La Rochefoucauld began early, and lasted throughout his life, and may well have prompted and shaped these thoughts." For additional evidence of Swift's interest in La Rochefoucauld see The Correspondence of Jonathan Swift, ed. F. Elrington Ball (London, 1911), II, 44; III, 297; IV, 277; v, 77; vI, 107-112. Also see "Verses on the Death of Dr. Swift," The Poems of Jonathan Swift, ed. Harold Williams (Oxford, 1958), p. 551. Although George Savile, first Marquis of Halifax, had written his aphorisms before Swift's, it was not until 1750 that the Political, Moral, and Miscellaneous Thoughts and Reflections was published. See H. C. Foxcroft, The Life and Letters of George Savile, Bart. (London, New York, and Bombay, 1898), II, 179, for the view that Halifax was influenced by La Rochefoucauld, "whose example, no doubt, he followed." Chesterfield, in a letter to his son dated 15 January 1753 , included a group of aphorisms "more calculated for the meridian of France or Spain than of England"; see The Letters of Philip Dormer Stanhope, 4th Earl of Chesterfield, ed. Bonamy Dobrée (London, 1932), v, 2005, n. 1, for this, young Stanhope's opinion of his father's aphoristic effort; also see the letter dated 5 September 1748, in which Chesterfield urges his son to study the Maximes.
} 
isms [as] his best work and as near as anything in English to the pensées of La Rochefoucauld."'

For many reasons, the aphorism as a genre has had a complex history. Most important of these, the form had no stable literary identity until fairly recent times. It was variously defined by lexicographers ${ }^{3}$ and usually undifferentiated from proverbial materials by Renaissance collectors of sententiae, ${ }^{4}$ moreover, it shared a somewhat confused ancestry with the seventeenth-century essay and character. ${ }^{5}$ Regarded by most scholars as a discrete composition, the aphorism was understood by others to be any pithy or otherwise telling sentence that might be excerpted from a longer piece and made to stand by itself. ${ }^{6}$ The genre is treated by a large and interesting literature, which the present study has necessarily taken into account, though it does not treat that material directly. ${ }^{7}$

Two kinds of aphorism are generally acknowl-
2 "William Shenstone," Essays in Criticism and Research (Cambridge, Eng., 1942), pp. 108-109. See also A. D. McKillop, English Literature from Dryden to Burns (New York and London, 1948), p. 230, who maintains that Shenstone wrote aphorisms "in the manner of La Rochefoucauld."

3 Representative of lexical imprecision are Johnson's Dictionary and the $O E D$, neither of which distinguishes very well between the meanings of "aphorism," "apophthegm," "maxim," "sentence," and "precept." If it is true that the illustrative passages following the definitions of these terms in the $O E D$ suggest that they cannot always be interchanged in context, it is also true that the definition of each employs some or all of the remaining words: "Aphorism" is in part defined as "Any principle or precept expressed in a few words; a short pithy sentence containing a truth of general import"; "Apophthegm," as "a pithy or sententious maxim." Johnson is hardly more helpful: "Aphorism" he defines as "A maxim; a precept contracted in a short sentence; an unconnected proposition." "Apophthegm" he considers to be "A remarkable saying; a valuable maxim uttered on some sudden occasion."

4 See, for example, William Baldwin, A Treatise of Morall Philosophie, Contaynyng the Sayinges of the Wyse (London, 1547). Surprisingly enough, Baldwin, although he prints proverbial and aphoristic materials together, without differentiating them by his format, makes an attempt (futile in my opinion) to distinguish between "Precepts, Counsails and Lawes" on the one hand and "Proverbs and Semblables" on the other (I, iv, 3). The means for distinguishing between the two forms were available to Renaissance authors; a sufficiently strong motive was not; that is, as early as 1546 John Heywood accurately limited himself to a selection of purely proverbial materials in his "Dialogue, Wherein are Pleasantlie contrived the Number of All The Effectual Proverbs In Our Old English Tongue," though most other authors did not. See The Proverbs of John Heywood, ed. Julian Sharman (London, 1874). Even Erasmus, who certainly was aware of the difference between various kinds of sententiae, as the first edition of his Adagia, 1500, makes clear, added, in later editions, folk sayings (proverbs) to the classical Greek and Roman sentences that make up the original volume. See Theodore Charles Appelt, Studies in the Contents and Sources of Erasmus' "Adagia" (Chicago, 1942), pp. 9-10. The inescapable inference (based on this and much more evidence) seems to be that although the learned authors of the Renaissance were quite aware of the distinctions between sententious forms, they were much more concerned with preserving the wisdom of valuable old sentences than with classifying them.

- Benjamin Boyce, The Theophrastan Character in England to 1642 (Cambridge, Mass., 1947), p. 81; Leon Levrault, Maximes et portraits (Paris, 1908); William G. Crane, Wit and Rhetoric in the Renaissance (New York, 1937), p. 132.
- This was, of course, standard medieval and Renaissance practice. See Crane, pp. 34-35. It is rather surprising to discover the much more recent literary surgery in Logan Pearsall Smith, A Treasury of English A phorisms (London, 1928).

${ }^{7}$ In addition to those already cited, the most useful studies consulted in the preparation of this essay were these: W. Blades, "Introduction," The Dictes and Sayings of the Philosophers, A Facsimile of the First Book Printed in England by William Caxton, 1477 (London, 1877); R. O. Evans, “Aphorism-An Aspect of Euphuism," $N \& Q Q$, cCI (1956), 278-279; W. Gemoll, Das A pophthegma (Leipzig, 1924); H. A. Grubbs, "The Originality of La Rochefoucauld's Maxims," RHL, xxxvI (1929), 18-59; M. Hadas, A History of Greek Literature (New York, 1950); W. C. Hazlitt, English Proverbs and Proverbial Phrases (London, 1907); W. R. Inge, Lay Thoughts of a Dean (London, 1926); J. Morley, A phorisms (London, 1887); F. Schalk, "Das Wesen des französischen Aphorismus," Die Neueren Sprachen, XLI (1933), 130-140, 421-436; W. W. Skeat, Early English Proverbs (Oxford, 1910); J. A. K. Thomson, Classical Influences on English Prose (London, 1956); M. P. Tilley, A Dictionary of the Proverbs in England in the Sixteenth and Seventeenth Centuries (Ann Arbor, Mich., 1950); B. C. Williams, Gnomic Poetry in Anglo Saxon (New York, 1914); Sister Mary Francine Zeller, New Aspects of Style in the Maxims of La Rochefoucauld (Washington, 1954). It was not until I had concluded the present study that I ran across Sister Mary's admirable dissertation on The Maximes, in which she sets out to analyze the characteristics and effects of La Rochefoucauld's constructions, rhythms, and melodies. Though her analysis is valuable, several aspects of her effort give me pause. (1) I believe Sister Mary often implies the view that the systematic description of characteristics of style is equivalent to an elucidation of their effects. (2) Her analysis of structure, which attempts to take into account all La Rochefoucauld's variations, has so large a number of categories that while it may be useful for reference, it does not give the reader a "sense" for the many forms. (3) Her willingness to venture frequent impressionistic responses perhaps mars the objectivity that characterizes her work at its best; for example, she says, "as one turns the pages of La Rochefoucauld's collection of Maxims, the constantly recurring tonic $i$ is noted quite easily. The high, shrill quality of this vowel seems to translate aptly the author's ironical overtones" (p. 77). Again, "The quick staccato quality of the consonants $d, p, k$, and $t$ is called up to render the anger, disgust, and sarcasm of the author, the rolling $r$ his rage, the whistling recurrrence of the $s$ his irony, disdain, and scorn, the abrasion of the $f$ and $v$ his disgust, while the softer sounds of $l, m, r$ rather translate the sweetness, languor, and evasive fluidity of the topic under consideration" (p. 81). The reader of both her study and the present essay will note that the aphoristic feature which I call "polar" Sister Mary had referred to as "binary," "bipartite," or "binomial." As the reader may gather, my unique aims have been (1) to establish 
edged to be typical of the seventeenth and eighteenth centuries in France and England-the open Baconian variety and the epigrammatic maxime by La Rochefoucauld. Franz H. Mautner has very usefully distinguished the mental processes from which these aphorisms spring and accordingly designated all such compositions to be products either of Einfall (flash of insight) or of Klärung (results of gradual clarification). ${ }^{8}$ Bacon, producing aphorisms in the secondnamed class - in the tradition of Hippocrateswrote in a style that was highly compressed and lucid, but not remarkable for any structural idiosyncracies. This technique permitted different parts of a large subject to be presented in short, pithy, discrete though related compositions-a perfect way of transmitting scientific data clearly. In Novum Organum, Bacon generally presents under the heading aphorism a statement of about one hundred fifty words. Each piece deals with one topic and uses very few devices of amplification to further the exposition. Here is an example of the form, typical in subject matter, development, and length.

But the Empirical school of philosophy gives birth to dogmas more deformed and monstrous than the Sophistical or Rational school. For it has its foundations not in the light of common notations, (which though it be a faint and superficial light, is yet in a manner universal, and has reference to many things,) but in the narrowness and darkness of a few experiments. To those therefore who are daily busied with these experiments, and have infected their imagination with them, such a philosophy seems probable and all but certain; to all men else incredible and vain. Of this there is a notable instance in the alchemists and their dogmas; though it is hardly to be found elsewhere in these times, except perhaps in the philosophy of Gilbert. Nevertheless with regard to philosophies of this kind there is one caution not to be omitted; for I foresee that if ever men are roused by my admonitions to betake themselves seriously to experiment and bid farewell to sophistical doctrines, then indeed through the premature hurry of the understanding to leap or fly to universals and principles of things, great danger may be apprehended from philosophies of this kind; against which evil we ought now to prepare. ${ }^{9}$

La Rochefoucauld's aphorisms are, of course, much briefer than Bacon's: and, as every reader knows, they contain a paradox, or "turn." Although the Frenchman's literary descendants were highly original aphorists, they were influenced by him in two ways. In the first place, he confined their aphoristic scrutiny largely to man's psychology, rather than to special fields of knowledge-medicine, statecraft, scientific methodas Hippocrates and Bacon earlier had done. In addition he gave them a device of style in his use of paradox, which tempts imitation despite its complexity. It seems probable that in addition to being attracted by the obvious subtlety of these compositions, the would-be imitators were attracted by an equally obvious symmetry. If such was their response, it was accurate. In fact the aphorisms of La Rochefoucauld and his followers employ structural elements to support their meaning in such specific ways that they lend themselves to analysis, which can characterize both the patterns of structure and-more interesting - the kind of cognition stimulated by each of these patterns.

Though few critics have tried to say why, it has often been observed that the form of these aphorisms is unmistakable:

On est quelquefois aussi différent de soi-même que des autres. ${ }^{10}$

Nous aimons toujours ceux qui nous admirent, et nous n'aimons pas toujours ceux que nous admirons. (La Rochefoucauld, p. 98)

Nous pardonnons souvent à ceux qui nous ennuient, mais nous ne pouvons pardonner à ceux que nous ennuyons. (La Rochefoucauld, p. 99)

The People can seldom agree to move together against a Government, but they can sit still and let it be undone. (Halifax, p. 219)

Men pretend to serve God Almighty who doth not need it, but make use of him because they need him. (Halifax, p. 221.)

a classification of aphoristic forms that is at once comprehensive, brief, and clear; (2) to discover the kinds of apprehension engendered by each variety of form.

${ }^{8}$ See "Der Aphorismus als literarische Gattung," Zeitschrift für Ästhetik und allgemeine Kunstwissenschaft, xxvII (1933), 154, where Professor Mautner observes, "Die zwei Hauptformen aphoristischer Zeugung sind Einfall und Klärung, jener der mögliche Ausgangs-, dieser ein Endpunkt bewußten Denkens."

${ }^{9}$ The Works of Francis Bacon, eds. James Spedding, R. L. Ellis, and D. D. Heath, 14 vols. (London, 1887-1902), IV, 65.

${ }^{10}$ La Rochefoucauld, Maximes, ed. F. C. Green (Cambridge, England, 1945), p. 74; hereafter cited as La Rochefoucauld. For the other aphorists these texts were used: Halifax, The Complete Works of George Savile, First Marquess of Halifax, ed. Walter Raleigh (Oxford, 1912); hereafter cited as Halifax. Jonathan Swift, $A$ Proposal for Correcting the English Tongue, Polite Conversation, Etc., (Vol. Iv, Blackwell ed.), ed. Herbert Davis with Louis Landa (Oxford, 1957); hereafter cited as Swift. Chesterfield, The Letters of Philip Dormer Stanhope, 4th Earl of Chesterfield, ed. Bonamy Dobrée, 6 vols. (London, 1932), v; hereafter cited as Chesterfield. William Shenstone, The Works in Verse and Prose of William Shenstone, ed. James Dodsley, 3 vols. (London, 1764-69), II; hereafter cited as Shenstone. The parenthesized numbers, with short citations, used after aphorisms quoted in the body of the present essay refer, of course, to page numbers in the texts named in this note. 
Small Causes are sufficient to make a Man uneasy, when great ones are not in the Way: For want of a Block he will stumble at a Straw. (Swift, p. 246)

Vision is the Art of seeing Things invisible. (Swift, p. 252)

It is with some men as with some horses; what is esteemed spirit in them proceeds from fear. (Shenstone, p. 224)

Spleen is often little else than obstructed perspiration. (Shenstone, p. 282)

Obviously, paradoxical aphorisms rely as much upon the force of style as upon intellectual acuity for their effect. Expository aphorisms, though by no means discursive, present arguments to render their conclusions more acceptable to the reader; in taking some time to make a single point, they attenuate their dogmatism. And because they do not demand the reader's attention as unwaveringly as do the paradoxical, his responsibility to judge seems diminished. Though such judgment may be no less profound than that required by the paradoxical, it is more deliberative. On the other hand, the immediacy and intensity of response to aphorisms like La Rochefoucauld's make them seem incontrovertible. To some extent, this feeling results from their concentration in space and reading time. To a greater extent, the feeling derives from the most obvious effect of paradox - the almost simultaneous destruction and reconstruction of received opinion. This change is wrought by a mischievous selection of contradictory views upon matters the reader has long regarded as settled.

About three-fourths of the paradoxical aphorisms of La Rochefoucauld, Halifax, Swift, Chesterfield, and Shenstone employ one of five distinct polar (grammatically balanced) structures. No matter whether they contain one, two, or three sentences, each of these compositions may be divided into two parts, which are related to each other by one of these five means: antithesis, analysis, synthesis, equation, or comparison. The remaining one-fourth, though paradoxical, are not strictly speaking polar. ${ }^{11}$

Illustrations of the first of these polar classes are readily come by: they employ easily recognized parallelism in which the members are related by antithesis:

Every Man desires to live long: but no Man would be old. (Swift, p. 246)

On peut trouver des femmes qui n'ont jamais eu de galanterie, mais il est rare d'en trouver qui n'en aient jamais eu qu'une. (La Rochefoucauld, p. 66)
I know not whether encreasing years do not cause one to esteem fewer people and to bear with more. (Shenstone, p. 294)

Aphorisms with polar elements related by analysis are also numerous. In these, as one might infer from their name, the first element presents a generalization and the second an elucidation by particulars.

A Difficulty raiseth the Spirits of a great Man; he hath a mind to wrestle with it and give it a Fall. (Halifax, p. 248)

La jalousie se nourrit dans les doutes, et elle devient fureur ou elle finit, sitôt qu'on passe du doute à la certitude. (La Rochefoucauld, p. 61)

It is generally a principle of indolence that makes one so disgusted with an artful character. We hate the confinement of standing centinels [sic] in our own defence. (Shenstone, p. 257)

Those of the third class, employing synthesis, adduce particulars in the first polar member and the generalization inferred from them in the second.

11 The following brief outline reveals in simple form the pattern of the classification adduced in the text.

I. Expository aphorisms

II. Paradoxical aphorisms

A. Polar paradoxical aphorisms

1. Polar aphorisms of parallel structure

a. parallelism of antithesis

b. parallelism of analysis

c. parallelism of synthesis

2. Polar aphorisms of equational structure

3. Polar aphorisms of comparative structure

B. Non-Polar paradoxical aphorisms

Paradoxical aphorisms that do not employ grammatically balanced elements to express the paradox (about 25\%) cannot be classified under the five headings provided in this study. Although I suspect great similarity between the effects of polar and non-polar compositions (in fact, I have been able to characterize some of the relationships between the two kinds of structures), space will not allow a full discussion of my tentative conclusions. Here is a very brief, and I hope not misleading, summary of my opinions. One might well regard polar aphorisms as making up the main corpus of paradoxical aphorisms and non-polar forms as constituting a slim appendage to the main body: the farther along the appendage the aphorisms occur, the fewer grammatically polar elements would they contain. Close to polar is this aphorism; in fact, if its adjective clause were made independent (an easily accomplished task), it would qualify: "L'intérêt, qui aveugle les uns, fait la lumière des autres" (La Rochefoucauld, p. 62). But at the other extreme are non-polar aphorisms that suggest little or nothing of grammatical polarity. "The vacant skull of a pedant generally furnishes out a throne and a temple for vanity" (Shenstone, p. 268). Whatever degree of polarity a paradoxical aphorism may have, obviously something in it must convey the force of paradox. In La Rochefoucauld (very nearly polar), "qui aveugle les uns" opposes "fait la lumière"; in Shenstone (scarcely polar), "vacant skull" paradoxically "furnishes out." 
No Man will take Counsel, but every Man will take Money; therefore Money is better than Counsel. (Swift, p. 253)

Ceux qu'on condamne au supplice affectent quelquefois une constance et un mépris de la mort qui n'est en effet que la crainte de l'envisager, de sorte qu'on peut dire que cette constance et ce mépris sont à leur esprit ce que le bandeau est à leurs yeux. (La Rochefoucauld, p. 59)

Aphorisms whose polar elements are related by equation are invariably metaphors of one sentence in which a copulative verb joins two nouns.

L'amour-propre est le plus grand de tous les flatteurs. (La Rochefoucauld, p. 56)

Just enough of a good thing is always too little. (Halifax, p. 255)

A Courtier's dependent is a beggar's dog. (Shenstone, p. 148)

The last kind is the polar aphorism of comparison. Although it occurs in a variety of forms, it is easily defined as an aphorism in which all the elements are part of a comparison. This example by La Rochefoucauld fulfills the terms of the definition.

Les passions de la jeunesse ne sont guère plus opposées au salut que la tiédeur des vieilles gens. (La Rochefoucauld, p. 103)

But the next, also La Rochefoucauld's, does not, in that all of its elements are not part of the comparison.

Il est de la reconnaissance comme de la bonne foi des marchands, elle entretient le commerce; et nous ne payons pas parce qu'il est juste de nous acquitter, mais pour trouver plus facilement des gens qui nous prêtent. (La Rochefoucauld, p. 87)

Following are several examples of the type:

Nothing is less forgiven than setting Patterns Men have no mind to follow. (Halifax, p. 215)

Eloquence, smooth and cutting, is like a Razor whetted with Oil. (Swift, p. 251)

There seem near as many people that want passion as want reason. (Shenstone, p. 256)

With the classification completed, a three-part thesis can be meaningfully offered. Even though it is complex and, logically, far-reaching, it can be simply expressed: first, both grammatical coordinates in paradoxical aphorisms say the same thing in different ways; more important, it is only in aphorisms of antithesis that the two opposing ideas in the paradox are conveyed severally by each of the two grammatical coordinates (paradox in each of the other four classes is conveyed by unique rhetorical means); most important, the opposing ideas in the paradox of every aphorism say the same thing in one important sense.

The most obvious means of accomplishing the reassertion of meaning peculiar to polarity is to say the same thing twice: in other words, to use the sort of parallel repetition one discovers, for example, in Genesis:

And [Issachar] bowed his shoulder to bear, and became a servant unto tribute.

And the arms of his hands were made strong.... Even by the God of thy father who shall help thee; and by the Almighty, who shall bless thee.

It is significant that aphorists avoid this means, without exception! The less obvious meansparallelism (of antithesis, analysis, synthesis), equation, and comparison-involve the psychology of the reader more intensely than does repetition, whose chief effect is heavy inexorability. In the other kinds of polarity the reader experiences nervous response, the disturbance that precedes cognition, frequently in an area of ignorance or in an area walled off by preconception. The force of repetition is mechanical; the force of the other devices of polarity is electric; through their use of paradox, they close the circuit between poles and transform the two into a unique one.

It is a commonplace that opposites like strongweak, love-hate, light-dark, despite the antitheses they represent, are so mutually interdependent for their meanings that while the analytical functions of mind distinguish them, the emotional functions associate them. "Odi et amo" says Catullus, speaking for himself as a lover, and suggesting that in the "opposites" of love and hate there is, in addition to analytical polarity, emotional association, perhaps congruence. La Rochefoucauld and Shenstone make similar observations.

Les passions en engendrent souvent qui leur sont contraires. L'avarice produit quelquefois la prodigalité, et la prodigalité l'avarice; on est souvent ferme par faiblesse, et audacieux par timidité. (La Rochefoucauld, p. 57)

It is a miserable thing to love where one hates; and yet it is not inconsistent. (Shenstone, p. 156)

Both of these compositions assert the psychological basis for all paradoxical aphorisms, for they implicitly allow that paradox may join as well as distinguish "opposites," a readily demonstrable phenomenon. 
Two views are suggested by Shenstone's aphorism "There is no word in the Latin language that signifies a female friend. 'Amica' means a mistress: and perhaps there is no friendship betwixt the sexes wholly disunited from a degree of love" (Shenstone, p. 171). The views are that sexual love on the one hand must have, on the other, need not have, a part in a relationship between the sexes. It is likely that most people hold both opinions simultaneously, but without consciousness of the logical contradiction. The aphorism disturbs this double view, ostensibly by rejecting one. Actually, what it does, however, is to require the reader to redefine "mistress": before the experience of the aphorism, a mistress is a woman with whom one enjoys a liaison: after the aphorism, any woman a man likes is a potential mistress. Further, the aphorism implicitly urges the reader to reconsider and discover love as an ingredient of every friendship he has enjoyed with a woman. In effect this paradox blurs the workaday distinction between women who are mistresses and women who are not by encouraging the appraisal of man's feelings about all women of his acquaintance as opposed to his experience with particular women.

In La Rochefoucauld's "La plupart des honnêtes femmes sont des trésors cachés qui ne sont en sûreté que parce qu'on ne les cherche pas" (La Rochefoucauld, p. 106) the paradox constitutes redefinition of a word, "virtue." "Honnêtes femmes" suggests that chastity is a moral absolute, but with the addition of the second clause, chastity becomes more nearly a product of circumstance. In implying its paradox, the aphorism does not choose between extremes: instead, it tempers one with the other. In short, the elements of paradox in these aphorisms are contradictory only at the most ordinary level of apprehension, only in a realm in which a mistress is simply a mistress, virtue simply virtue. Their actual function is to redefine terms about which there are misconceptions and preconceptions, to remove the insulation of prejudice from words to which faulty or circumscribed meanings attach.

One might suppose that only aphorisms employing the parallelism of antithesis could rely on such fusing opposition. Swift's "Every Man desires to live long: but no Man would be old" plays on an obvious contradiction between the desire for longevity and the dislike of old age, which inevitably attends it. And indeed this class presents its paradox in the most straightforward possible way. The first polar element contains the first part of the paradox, and the second element, the second. One may observe this simple relationship by comparing grammatical coordinates with the ideas in the paradox below them:

Every Man desires to live long: but no Man would be old. (Swift, p. 246)

The paradox: Every man desires to live long; no man desires to live so long that he suffers the disabilities of age.

Dans les premières passions les femmes aiment l'amant, et dans les autres elles aiment l'amour. ( $\mathrm{La}$ Rochefoucauld, p. 119)

The paradox: Women always love their lovers; women love only love, after their first affairs.

Contrary to early expectation, not only this but the other four classes of polar aphorisms produce the unifying tension between paradoxical elements. Below are examples employing the parallelism of analysis, synthesis, equation, and comparison. For the moment, the reader need only observe, as he reads, that in aphorisms of these classes the grammatical coordinates do not state the contradictory elements of the paradox. Not readily observable, therefore, the paradox must be inferred.

\section{Examples of Analysis}

The Dissimulation of a Fool should come within the Statute of Stabbing. It giveth no Warning. (Halifax, p. 235)

The inferred paradox: The dissimulation of a fool is so clumsy as to be readily observed and countered; the dissimulation of a fool is so unlooked for as to be dangerous.

La fidélité qui paraît en la plupart des hommes n'est qu'une invention de l'amour-propre pour attirer la confiance; c'est un moyen de nous élever au-dessus des autres et de nous rendre dépositaires des choses les plus importantes. (La Rochefoucauld, p. 91)

The inferred paradox: Loyalty is a virtue practiced for its own sake; loyalty is a means of securing both the good will of others and a good opinion of ourselves.

\section{Examples of Synthesis}

There is no word in the Latin language that signifies a female friend. "Amica" means a mistress: and perhaps there is no friendship betwixt the sexes wholly disunited from a degree of love. (Shenstone, p. 171)

The inferred paradox: In Man's relationships with women sexual love need have no part; in man's relationships with women, sexual love always plays some part.

At court people embrace without acquaintance, serve one another without friendship, and injure one another without hatred. Interest, not sentiment, is the growth of that soil. (Chesterfield, p. 2001)

The inferred paradox: In courts, men's good and evil actions are the result of benevolence and dislike; in courts, men's good and evil actions are the result of policy. 


\section{Examples of Equation}

Le refus des louanges est un désir d'être loué deux fois. (La Rochefoucauld, p. 77)

The inferred paradox: The refusal of praise is the result of modesty; the refusal of praise is the result of vanity.

A Courtier's dependent is a beggar's dog. (Shenstone, p. 148)

The inferred paradox: A courtier's dependent is what most people imagine: a man of some slight importance; $\boldsymbol{a}$ courtier's dependent is a beggar's dog.

\section{Examples of Comparison}

La plupart des honnêtes femmes sont des trésors cachés qui ne sont en sûreté que parce qu'on ne les cherche pas. (La Rochefoucauld, p. 106)

The inferred paradox: Virtuous women and hidden treasures have nothing in common; most virtuous women and hidden treasures have this in common: both are safe only when they are unsought.

Some People take more Care to hide their Wisdom than their Folly. (Swift, p. 244)

The inferred paradox: All people are ashamed of their folly and proud of their wisdom; some people (because of modesty or prudence?) are more willing to acknowledge their folly than their wisdom.

The unique logic by which paradox is derived from each class implies that each achieves its effects differently from the simpler antithetical form. Among these other kinds, the analytical, it will be recalled, use deductive logic: their first grammatical coordinate states a generalizationa minor premise, in fact-and the second in some way elucidates it. Here is one of Shenstone's, earlier quoted.

(1) Poets seem to have fame in lieu of most temporal advantages. (2) They are too little formed for business to be respected: too often feared or envied to be beloved. (Shenstone, p. 173)

In this next aphorism, one employing synthesis, the function of the coordinate elements is reversed: that is, the first member contains details of evidence, and the second, the inference.

(1) At court people embrace without acquaintance, serve one another without friendship, and injure one another without hatred. (2) Interest, not sentiment, is the growth of that soil. (Chesterfield, p. 2001)

Because most aphorisms present judgments about human psychology based on general experience, knowledgeable readers will have available to them the evidence adduced by many of these analytical and synthesizing forms. When such a reader sees the evidence isolated from other data and arranged for argument (as in step one of aphorisms of synthesis), he can often infer step two, a generalization very like the aphorist's; and the same reader, after seeing the generalization (as in step one of aphorisms of analysis), may search his own mind for heretofore unselected but available data that will make up step two. When Shenstone says that "Poets seem to have fame in lieu of most temporal advantages," he makes a statement the reader regards as true-even before finishing the aphorism-if he can discover evidence in his own experience to support it.

But to grasp the fundamental effect of these types, one requires an important corollary of this mutual potentiality for derivation between their parallel members: if it is true that each such member contains a different form of the idea found in both, then each must in its own way imply the entire aphoristic paradox! One may wonder why the writer does not then content himself with a non-parallel aphorism of one member. Sometimes he does. ${ }^{12}$ But more often parallelism is employed to offer another tier of illumination, a second order of paradox reinforcing the first. In fact, such aphorisms make an almost simultaneous appeal to both the inductive and deductive reasoning faculties. Deduction of course moves slowly, point by point, from the known whole to its separated parts; induction, considered as a process of thought rather than as a method of investigation, is less consciously controlled. It sweeps through myriads of data, selecting the pertinent, and, in some way unknown to consciousness, synthesizes the parts into a newly created whole. Although it can be deliberate, the most measured inductive investigation requires that final leap. Conducted along the doublelevelled route, a close reader of analytical and synthesizing aphorisms cannot avoid both deductive and inductive cognition of the single truth they contain.

The effects of structure in aphorisms of equation and comparison are also unique. The basis of meaning in such compositions is the illogical discovery of "similitude in dissimilitude," to use Wordsworth's appropriate paradox. Whether the form makes use of metaphor (equation) or simile (comparison) the means by which the paradox is produced are markedly alike, if not the same. Instead of stimulating an initial opposition and

12 Swift, for example, writes, "No wise man ever wished to be younger." Although the aphorism does not contain parallel elements, a paradox may be readily inferred from it: Men prefer youth to old age; men (wise men) do not prefer to youth old a\&e; its purpose, of course, is to modify the meaning of "wise men" through the denial of received opinion that it is better to be young than old. 
subsequent fusion of disparates (antithesis) or offering a paradox both inductively and deductively expressed (analysis, synthesis), aphorisms of equation and comparison provide, in effect, definitions that seem at variance with common sense, but which prove well founded. The reader will recall these:

Just enough of a good thing is always too little. (Halifax, p. 255)

Some People take more Care to hide their Wisdom than their Folly. (Swift, p. 244)

The paradox itself results from the tension between the standard definition, which remains unstated, and the figurative one asserted by the aphorist; its effect is achieved as the metaphoric truth displaces (at least modifies) the literal in the mind of the reader. It is worth observing that the everyday definition, though unexpressed, is in a very real sense brought to the attention of the reader. For he seeks it out and clings to it if his imagination is made uncomfortable as it comes to grips with the aphoristic; or if he quickly accepts the metaphor, part of its meaning will derive from the nature and degree of its deviation from the standard definition. In either case both elements of the paradox are available to him. In what sense then are the two definitions (elements of paradox) the same? Simply in this. The standard definition can never again be wholly accepted; it must afterwards partake of the metaphoric. On the other hand the standard is obviously grounded in palpable reality and can never be entirely forsaken. Each then is tempered by the other, and they become one.

Obviously, aphorisms have a special rhetorical and psychological unity. Their effects vary from class to class, but each one contains two components that must join to complete its meaning. The nature of the relationship so far found to exist between these two parts suggests that their order may be reversed without robbing the aphorism of its power. Curiously enough one has the opposite impression as he reads, and indeed the elements up to the very last seem somehow less important than the final one.

A man who tells nothing, or who tells all, will equally have nothing told him. (Chesterfield, p. 1998)

In what appears to be the delayed revelation of "will equally have nothing told him" there seems an additional charge. But the circuit is closed only because the second pole is joined to the first, not because it was joined in a preferred sequence. Here are typical aphorisms, and they all sustain the illusion that last place is "best."
La plupart des honnêtes femmes sont des trésors cachés qui ne sont en sûreté que parce qu'on ne les cherche pas. (La Rochefoucauld, p. 106)

A Fool hath no Dialogue within himself, the first Thought carrieth him without the Reply of a second. (Halifax, p. 236)

A Poet, that fails in writing, becomes often a morose critick. The weak and insipid white-wine makes at length a figure in vinegar. (Shenstone, p. 186)

A very little wit is valued in a woman; as we are pleased with a few words spoken by a parrot. (Swift, p. 247)

Explaining is generally half confessing. (Halifax, p. 238)

Here, with their parallel members in reverse order, are the aphorisms quoted immediately above. They are just as telling, and their meanings (hairsplitting apart) the same.

Les choses ne sont en sûreté que parce qu'on ne les cherche pas: tels que les trésors cachés et la plupart des honnêtes femmes.

The first thought carrieth a fool without the reply of a second; he hath no dialogue within himself.

Weak and insipid white-wine makes at length a figure in vinegar just as a poet that fails in writing often becomes a morose critic.

We are pleased with very few words spoken by a parrot, just as we value a very little wit in women.

A way of half confessing is explaining.

Clearly, the important idea is not presented terminally, nor is a merely intellectual resolution contained in the final element. The reversibility of the order of polar elements commands the inference that before the conflict of paradox can be generated, both must be given or implied; hence, the reader experiences the sense of completion when he finishes the second polar element, whether it occurs in the original or in inverted order. Furthermore, meaning here is achieved not only as a result of the logical relationship between the elements, in which sequence would play an important part, but also (principally) as a result of the psychological association of contraries or opposites.

Men have two minds, one known to themselves and one unknown or only slightly known. With no obvious difficulty, they can often live as if only the known one existed, and as a result, their vision is limited to a perception of the ordinary, the thin life that parades in Plato's cave of shadows. How to shock or coax them into clearing a passageway from that comfortable known 
world to the richer world of refractory forms has been the concern of poets since the earliest times. Tragedy often does this work by destroying the known and thrusting its Oedipus or its Hamlet into a chaos out of which the hero must wrest a new order or perish. Whether he precipitates his own tragic fate-Lear and his division of the kingdom, Orestes and his matricide-or finds himself the pawn of rude circumstance-Hamlet summoned to rotten Elsinore-the potential effect is the same. The hero may experience a transformation, an enlargement of his perception, because he is forced to incorporate into consciousness elements from the world into which he has been thrust, a world he had long left unregarded. The aphorism, in a much more confined way, of course, forces a similar passage between the world of commonplace truth and its paradoxically related opposite, and in the process it renders a definition of its subject that is larger and truer than the one available to the apathetic scrutiny of the workaday world.

Despite its power to induce the shock of recognition, the aphorism can be a misleading teacher, simply for the reason that all its paradoxically energized circuits are closed systems. Tragedy involves its audience in a host of related ideas and feelings, delivering an impact that is multifarious as well as single; it sometimes destroys (and reconstructs) whole worlds. The aphorism, on the other hand, can follow only the course prescribed by its paradox. In fact, each composition is a well insulated and self-contained circuit; a completed idea for having merged thought and feeling; a cunning little world with its own revolutionary iconoclast and psychologist-restorer. As it thrusts at its reader, the aphorism penetrates to discrete sections of the mind-each an entity, but each only a small part of the entire man. Because "one thought fills immensity," the danger in this profound, though limited, completeness may be the reader's willingness to accept the illusion that he has been shown a more extensive truth than in fact he has. He should be aware that the incontrovertible character of the aphorism makes it not only unanswerable but also finite in its effect.

Yet in its own way, within the limits imposed by its logical and psychological nature, the aphorism teaches well. It is the young man's goad and the mature man's reminder. Its individualized paradoxical assault stimulates a breath-taking analytical arrest and examination of feeling. How after all does one achieve understanding except under the duress of some order of paradox? How is an opinion altered unless it is caught between what was and what can be? All learning worth the name involves the murder of an old idea by a new one. Paradoxical aphorisms are among the beneficent executioners of decrepit ideas, and they do their work in a handful of orderly ways.

Columbia University

New York 27, N.Y. 